\title{
PENGEMBANGAN SOAL PENALARAN \\ MODEL TIMSS MATEMATIKA SMP
}

\author{
1) Amrina Rizta, ${ }^{2)}$ Zulkardi, ${ }^{3)}$ Yusuf Hartono \\ ${ }^{1,2,3)}$ Universitas Muhammadiyah Palembang, Universitas Sriwijaya \\ ${ }^{1)}$ rina110389@gmail.com, ${ }^{2)}$ zulkardi@yahoo.com, ${ }^{3)}$ y.hartono@unsri.ac.id
}

\begin{abstract}
Abstrak
Penelitian ini bertujuan mengembangkan soal penalaran model TIMSS pada mata pelajaran matematika SMP yang valid dan praktis. Metode penelitian yang digunakan research and development. Kevalidan diketahui dari hasil penilaian validator pada lembar validasi yang menyatakan soal-soal yang dikembangkan telah baik berdasarkan content (sesuai dengan kurikulum dan materi), construct (sesuai dengan karakteristik/indikator penalaran), dan bahasa (sesuai dengan kaidah bahasa yang berlaku/EYD) dan kepraktisan diketahui dari hasil uji coba one-to-one dan small group. Hasil penelitian berupa soal penalaran model TIMSS matematika SMP yang valid dan praktis. Hasil uji coba diperoleh rata-rata hasil tes penalaran siswa adalah 4 siswa $(14,815 \%)$ tergolong mempunyai penalaran yang sangat baik, 4 siswa $(14,815 \%)$ tergolong memunyai penalaran yang baik, 8 siswa $(29,63 \%)$ tergolong mempunyai penalaran yang sedang, 6 siswa $(22,22 \%)$ tergolong mempunyai penalaran yang rendah, dan 5 siswa $(18,52 \%)$ tergolong mempunyai penalaran yang sangat rendah. Berdasarkan hasil tersebut maka kemampuan penalaran siswa tersebut tergolong sedang.
\end{abstract}

Kata kunci: penelitian dan pengembangan, soal penalaran, TIMSS, matematika, SMP

\section{DEVELOPING REASONING QUESTION MODEL OF SMP TIMSS MATH PROBLEMS}

\author{
1) Amrina Rizta, ${ }^{2)}$ Zulkardi, ${ }^{3)}$ Yusuf Hartono \\ ${ }^{1,2,3)}$ Universitas Muhammadiyah Palembang, Universitas Sriwijaya \\ ${ }^{1)}$ rina110389@gmail.com, ${ }^{2)}$ zulkardi@yahoo.com, ${ }^{3)}$ y.hartono@unsri.ac.id
}

\begin{abstract}
This research is aimed to develop valid and practical TIMSS model of questions in junior high school course. This research used research and development method. The validity is discovered from validator assessment in validation sheet stating the questions is well based on content (in accordance with curriculum and subject), construct (in accordance with reasoning characteristics/indicator) and language (in accordance with Bahasa applied rule), and the Ppracticality is discovered from one-to-one and small group try-out. The research products are in the form of TIMSS model reasoning questions in junior high school mathematics course which are valid and practical. The Eexperiment results from the reasoning test show that there are four students $(14,815 \%)$ fine, four students $(14,815 \%)$ good, eight students $(29,63 \%)$ fair, six students $(22,22 \%)$ low, five students $(18,52 \%)$ poor. Those results showthat mathematical reasoning of student is good.
\end{abstract}

Keywords: Research and development, reasioning question, TIMSS, Mathematics, SMP 


\section{Pendahuluan}

Kemampuan penalaran matematis merupakan salah satu kemampuan yang penting untuk dilatihkan sejak dini pada siswa. Pentingnya kemampuan tersebut terlihat di dalam KTSP melalui Permendiknas Nomor 22 Tahun 2006 yang menyatakan bahwa salah satu tujuan pendidikan matematika SMP/MTs adalah agar setiap peserta didik memiliki kemampuan menggunakan penalaran pada pola dan sifat, melakukan manipulasi matematika dalam membuat generalisasi, menyusun bukti, atau menjelaskan gagasan dan pernyataan matematika. Begitupula di dalam Kurikulum 2013, dijelaskan bahwa salah satu kompetensi inti dalam pembelajaran khususnya untuk kelas VIII dan IX SMP adalah mengolah, menyaji, dan menalar dalam ranah konkret dan ranah abstrak sesuai dengan yang dipelajari di sekolah dan sumber lain yang sama dalam sudut pandang/teori.

Penalaran secara matematika mencakup kemampuan logika, dan berpikir sistematis. Menurut Brodie (2010, p.9), penalaran matematika merupakan suatu proses pemikiran yang menghubungkan pengetahuan baru dengan pengetahuan yang telah dimiliki, dan kemudian mengatur kembali pengetahuan yang didapatkan. Sementara itu menurut Keraf (1982, p.5), penalaran merupakan proses berpikir yang berusaha menghubung-hubungkan fakta-fakta atau evidensi-evidensi yang diketahui menuju kepada sua-tu kesimpulan. Dapat disimpulkan bahwa penalaran merupakan suatu proses berpikir dalam menentukan sebuah kesimpulan dari suatu pengetahuan baru yang diterima dengan cara mengaitkannya dengan pengetahuan yang telah dimiliki sebelumnya.

Standar kemampuan pembelajaran matematika di dalam The National Council of Teachers of Mathematics (NCTM) menyebutkan bahwa penalaran matematis dapat dilatih/dikembangkan salah satunya dengan cara melatih penalaran dalam menyelesaikan soal (Van den Walle, 2008, p.4). Berdasarkan NCTM tersebut diketahui bahwa salah satu cara untuk melatih kemampuan penalaran siswa adalah melalui pemberian soalsoal penalaran yang didesain khusus. Siswa yang terbiasa menyelesaikan soal-soal tersebut secara tidak langsung mengembangkan proses berpikir nalarnya. Dalam menyelesaikan permasalahan baik itu pada pelajaran matematika maupun permasalahan dalam kehidupan sehari-hari yang membutuhkan penalaran siswa dapat mengatasinya dengan baik. Hal tersebut sesuai dengan yang diungkapkan oleh Permana \& Utari (2007, p.116) bahwa penalaran merupakan kemampuan dasar matematika yang harus dikuasai siswa, sebab dengan penalaran dapat membantu siswa dalam menyelesaikan permasalahan-permasalahan matematika yang ditemui baik di sekolah maupun di kehidupan sehari-hari.

Gambaran yang tampak dalam proses pembelajaran matematika selama ini adalah soal-soal yang diberikan oleh guru lebih menekankan pada pemahaman konsep, sedangkan proses pemikiran tinggi termasuk bernalar jarang dilatihkan. Hal ini sesuai dengan hasil penelitian yang dilakukan Iryanti (2010, p.112) yang menunjukkan bahwa sebesar $57 \%$ persentasi waktu pembelajaran matematika di Indonesia lebih banyak digunakan untuk membahas atau mendiskusikan soal-soal dengan kompleksitas rendah, dan hanya sekitar 3\% waktu yang digunakan untuk membahas soal-soal dengan kompleksitas tinggi. Tidaklah heran jika kemampuan siswa Indonesia di tingkat internasional masih rendah.

Ada beberapa faktor yang menyebabkan guru jarang melatihkan soal-soal tingkat tinggi terutama yang membutuhkan penalaran. Di antaranya adalah guru belum mampu membuat sendiri soal-soal yang sesuai dengan indikator penalaran. Selain itu, belum banyaknya referensi soal-soal penalaran yang dikembangkan yang dapat digunakan secara langsung dalam proses pembelajaran. Faktor lain adalah masih ada guru yang enggan untuk memberikan soal-soal yang membutuhkan proses berpikir yang setingkat lebih sulit karena akan menghabiskan waktu lebih banyak pada proses pembelajaran. 
Untuk itu, diperlukan pengembangan soal-soal yang dapat melatih kemampuan bernalar siswa. Walaupun pada penelitian sebelumnya telah dilakukan pengembangan soal penalaran SMP oleh beberapa peneliti di antaranya Emilya (2010) tentang soal penalaran tipe open ended materi lingkaran, dan Jurnaidi (2012) tentang soal penalaran model PISA untuk konten change and relationship. Namun, soal-soal yang dikembangkan berupa soal uraian, dan belum ada yang berupa soal objektif yang berbentuk pilihan ganda. Walaupun soal pilihan ganda mempunyai kelemahan untuk siswa berspekulasi. $\mathrm{Na}$ mun, dapat diminimalisasikan dengan mengembangkan soal-soal penalaran yang mengacu pada TIMSS.

TIMSS merupakan studi internasional yang diselenggarakan untuk mengukur kemajuan dalam pembelajaran matematika dan IPA. Soal-soal TIMSS sebagian besar berupa soal pilihan ganda. Soal-soal tersebut mempunyai dimensi penilaian kognitif yang berbeda-beda salah satunya adalah penalaran. Pada domain kognitif penalaran, soalsoal pilihan ganda tersebut mencakup kemampuan mengalisa (analyze), menggeneralisasi (generalize), mengintegrasi (integrate), memberikan alasan (justify), dan memecahkan soal non-rutin (solve non-routine problems) (Mullis et al, 2009, p.46). Selain itu, soal-soal model TIMSS tidak hanya menggunakan rumus tetapi juga mengharuskan siswa untuk menggunakan kemampuan bernalarnya dalam proses penyelesaiannya, sehingga mengharuskan siswa untuk menuliskan uraian jawaban sebelum memilih option yang disediakan.

Hal ini sesuai dengan yang dikemukakan oleh Yunengsih (2008, p.36) bahwa soal-soal ranah kognitif dalam TIMSS banyak menekankan pada pemecahan masalah sehingga dapat dijadikan acuan untuk merumuskan soal-soal untuk mengukur tingkatan ranah kognitif. Oleh sebab itu, TIMSS dijadikan acuan untuk mengembangkan soal penalaran dalam penelitian ini. Selain itu, alasan TIMSS dijadikan acuan dalam pengembangan soal pada penelitian ini adalah karena materi soal-soal yang ada pada soal
TIMSS hampir semuanya terdapat pada kurikulum di Indonesia. Dari uraian sebelumnya, maka tujuan dalam penelitian ini adalah mengembangkan soal penalaran model TIMSS matematika SMP.

\section{Metode Penelitian}

Metode penelitian menggunakan model penelitian dan pengembangan (research and development). Menurut Zulkardi (2002, p.20), tahapan pengembangan soal terdiri dari dua tahapan utama yaitu tahapan preliminary (tahap persiapan) dan tahapan formative evaluation. Pada tahapan formative evaluation ini langkah yang diambil mengikuti langkah-langkah yang dikemukakan oleh Tessmer (1998, p.35) yang meliputi (1) self evaluation, (2) prototyping (expert review, one-toone, dan small group), dan (3) field test.

Pada tahapan preliminary, peneliti melakukan analisis siswa, analisis kurikulum SMP, dan analisis soal-soal TIMSS. Selanjutnya, dilakukan pendesainan perangkat soal yang meliputi kisi-kisi soal dan soal penalaran model TIMSS. Setelah menghasilkan kisi-kisi soal dan soal-soal penalaran model TIMSS dilanjutkan pada tahapan formative evaluation.

Pada tahapan formative evaluation, tahap pertama dilakukan self evaluation yang Peneliti melakukan penilaian sendiri terhadap hasil desain soal-soal yang telah dibuat. Hasilnya disebut sebagai prototype I. Selanjutnya, dilakukan tahap prototyping yang terdiri dari expert review, one-to-one, dan small group. Tahap expert review merupakan tahap uji validitas yang dilakukan oleh para pakar (expert) atau tenaga pendidik yang telah berpengalaman. Para pakar tersebut menilai dan menguji prototype I dengan cara dicermati, dinilai, dan dievaluasi menggunakan telaah dari segi konten, konstruk, dan bahasa. Saran-saran dari pakar ditulis pada lembar validasi dan kartu soal.

Secara paralel (bersamaan), juga dilakukan tahap one-to-one. Pada tahap ini prototype I diujicobakan kepada tiga orang siswa sebagai tester yang diminta untuk mengerjakan soal-soal yang telah dikembangkan dan 
juga diminta untuk memberikan komentar/ tanggapan terhadap soal yang telah mereka kerjakan. Hasil atau temuan yang diperoleh pada tahap expert review dan one-to-one dijadikan bahan pertimbangan dalam merevisi prototype I. Setelah prototype I direvisi akan menghasilkan prototype II. Prototype II ini selanjutnya diujicobakan pada tahap small group. Pada tahap ini, enam orang siswa diminta menyelesaikan soal-soal di prototype II dan juga komentarnya terhadap soal yang telah dikerjakan. Komentar dan temuan pada tahap small group ini dijadikan bahan pertimbangan dalam merevisi Prototype II.

Hasil dari revisi prototype II dinamakan prototype III. Sebelum dilanjutkan ke tahap field test, peneliti melakukan uji coba untuk melihat tingkat kesukaran soal, daya pembe$\mathrm{da}$, dan juga reliabilitas. Hasilnya dianalisis dan dibahas sehingga menghasilkan saransaran untuk memperbaiki prototype III sehingga menghasilkan prototype akhir. Prototype akhir inilah yang diujicobakan kepada subjek penelitian yaitu siswa kelas VIII.7 sebanyak 27 siswa dari SMPN 1 Palembang yang dilakukan pada semester genap 2012/ 2013. Hasil dari field test tersebut akan dilakukan perhitungan terhadap skor dari setiap siswa dan digunakan sebagai dasar penilaian terhadap kemampuan penalaran matematisnya.

Instrumen pengumpulan data yang digunakan dalam penelitian ini adalah lembar validasi dan tes. Lembar validasi digunakan untuk mendapatkan informasi dari para ahli sebagai expert judgement untuk memberikan masukan dan saran tentang soal yang dihasilkan. Tes digunakan untuk mendapatkan informasi tentang kepraktisan dan keefektifan soal yang dikembangkan serta kemampuan penalaran siswa.

Teknik analisis data yang digunakan adalah dengan menilai tingkat kelayakan, kualitas, dan ketepatan instrumen yang dihasilkan. Perangkat soal yang dikembangkan memperhatikan tiga kriteria yang diambil dari kriteria yang dikemukakan oleh Nieveen (2007, p.94) yaitu valid, praktis, dan efektif. Instrumen dikatakan valid apabila hasil validasi dari pakar mengatakan bahwa soal-soal yang dikembangkan sudah valid baik dari segi konten, konstruk, dan bahasa. Selain itu, instrumen dikatakan praktis apabila soal yang dikembangkan dapat digunakan oleh semua praktisi pendidikan matematika dan para pakar yang menjadi validator soal menyatakan bahwa soal yang dikembangkan dapat diterapkan. Sedangkan instrumen dikatakan efektif (Van den Akker, 1999, p.10) apabila para pakar dan praktisi berdasarkan pengalamannya menyatakan bahwa instrument (soal) mempunyai efek potensial terhadap kemampuan siswa yang dalam ini adalah kemampuan penalaran.

\section{Hasil Penelitian dan Pembahasan}

\section{Hasil Penelitian}

\section{Tahap Preliminary}

Tahap ini dilakukan analisis terhadap siswa, kurikulum SMP, dan juga soal-soal TIMSS untuk mengetahui materi apa saja yang menjadi domain konten yang ada di TIMSS. Tahap ini bertujuan untuk mengidentifikasi dan memilih materi esensial yang akan dijadikan domain konten pada soal yang dikembangkan. Setelah perangkat soal dikembangkan, tahap selanjutnya adalah mengembangkan soal penalaran model TIMSS, kisi-kisi soal, dan kartu soal. Salah satu soal dari produk awal (Prototype I) sebelum divalidasi oleh ahli dapat dilihat pada Gambar 1. 


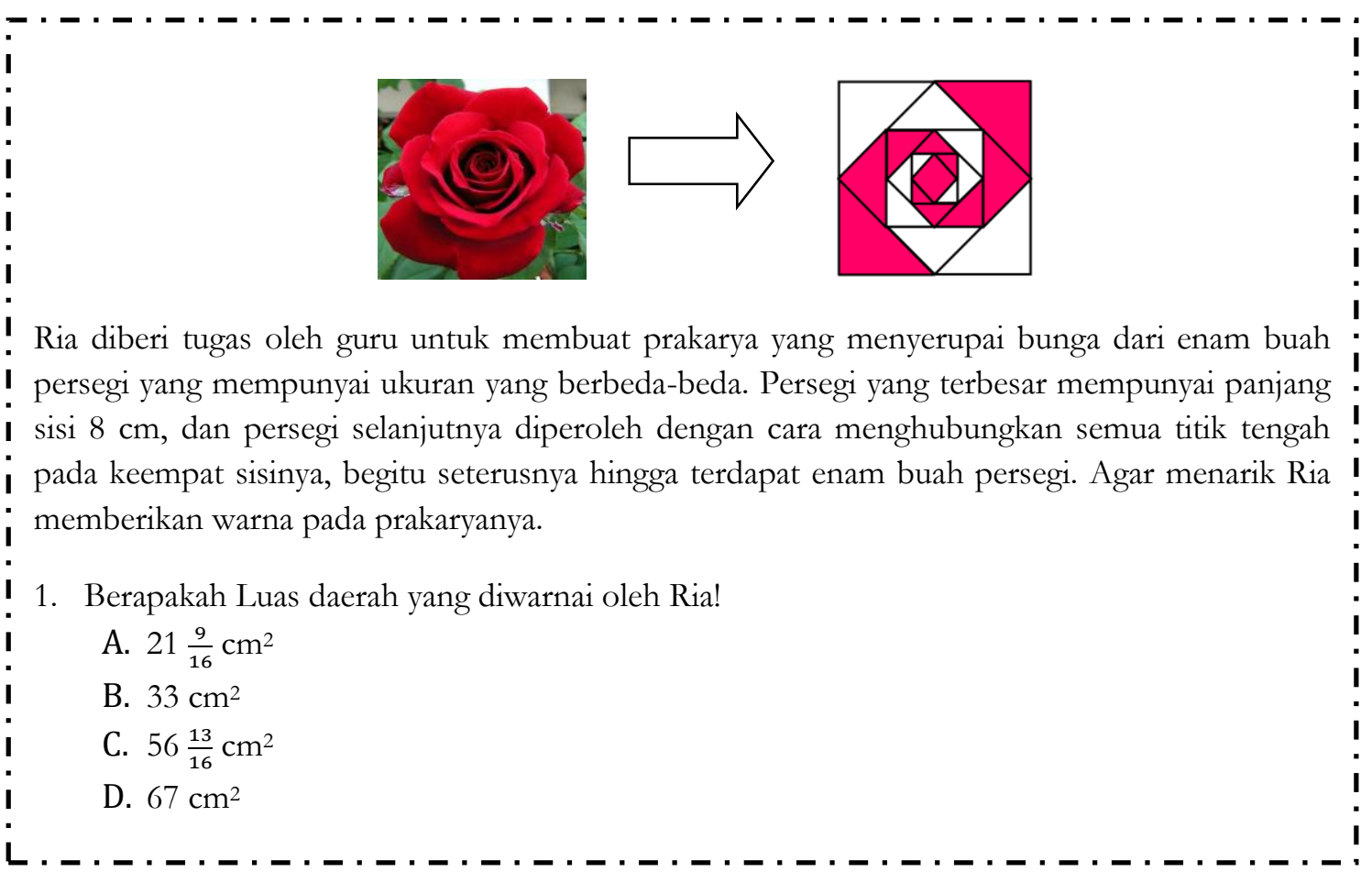

Gambar 1. Salah Satu Soal pada Produk Awal (Prototype I) sebelum Divalidasi

\section{Expert reviews}

Tahap ini melibatkan beberapa validator yaitu Dr. Endang Mulyana dari UPI, dan Fadjar Shadiq, M.App.Sc dari PPPPTK. Selain itu, beberapa teman sejawat yang ikut membantu memvalidasi soal-soal yang dikembangkan yaitu Heny Yuliana, S.Si., M.Pd guru matematika SMPN 3 Gelumbang dan Marion, S.Pd guru matematika SMPN 1 Tanjung Raja.

Proses validasi dilakukan melalui email dan walktrough. Validasi melalui email yaitu dengan Dr. Endang Mulyana, Fadjar Shadiq, M.App.Sc dan Marion, S.Pd. sedangkan validasi melalui walktrough dengan Henny Yuliana, S.Si., M.Pd. berdasarkan uji validasi oleh pakar dan teman sejawat maka dapat disimpulkan soal-soal penalaran model TIMSS yang dikembangkan sudah tergolong baik (valid), walaupun masih diperlukan perbaikan-perbaikan berdasarkan saran dan tanggapan validator.

One-to-one

Bersamaan dengan proses validasi dari para validator dan teman sejawat, prototype I juga diujicobakan pada tiga siswa kelas VIII yang berasal dari sekolah yang berbeda-beda dan memiliki kemampuan yang berbeda pula yaitu tinggi, sedang, dan rendah. Ketiga siswa tersebut adalah Ica Kurnia Sari (MTs. Muqimus Sunnah Palembang), Oki Rachmalia Rozi (SMPN 1 Palembang), dan Erika Agustina Putri (SMPN 1 Tanjung Raja). Selain diminta untuk mengerjakan soal, siswa juga diminta untuk mengomentari soal-soal yang telah dikerjakan. Tujuannya adalah untuk melihat kepraktisan soal.

Ketiga siswa tersebut diminta untuk mengerjakan soal pilihan ganda yang berjumlah 15 soal selama 120 menit. Selain itu, setiap siswa juga diminta untuk menjawab beberapa pertanyaan tentang soal-soal yang telah dikerjakan. Jawaban siswa tersebut akan digunakan sebagai acuan untuk memperbaiki prototype I.

Berdasarkan saran/komentar dari pakar, teman sejawat dan one-to-one yang telah didapatkan, maka soal-soal pada prototype I diperbaiki dan direvisi kembali. Salah satu soal yang telah direvisi dari prototype I yang disebut prototype II dapat dilihat pada Gambar 2. 


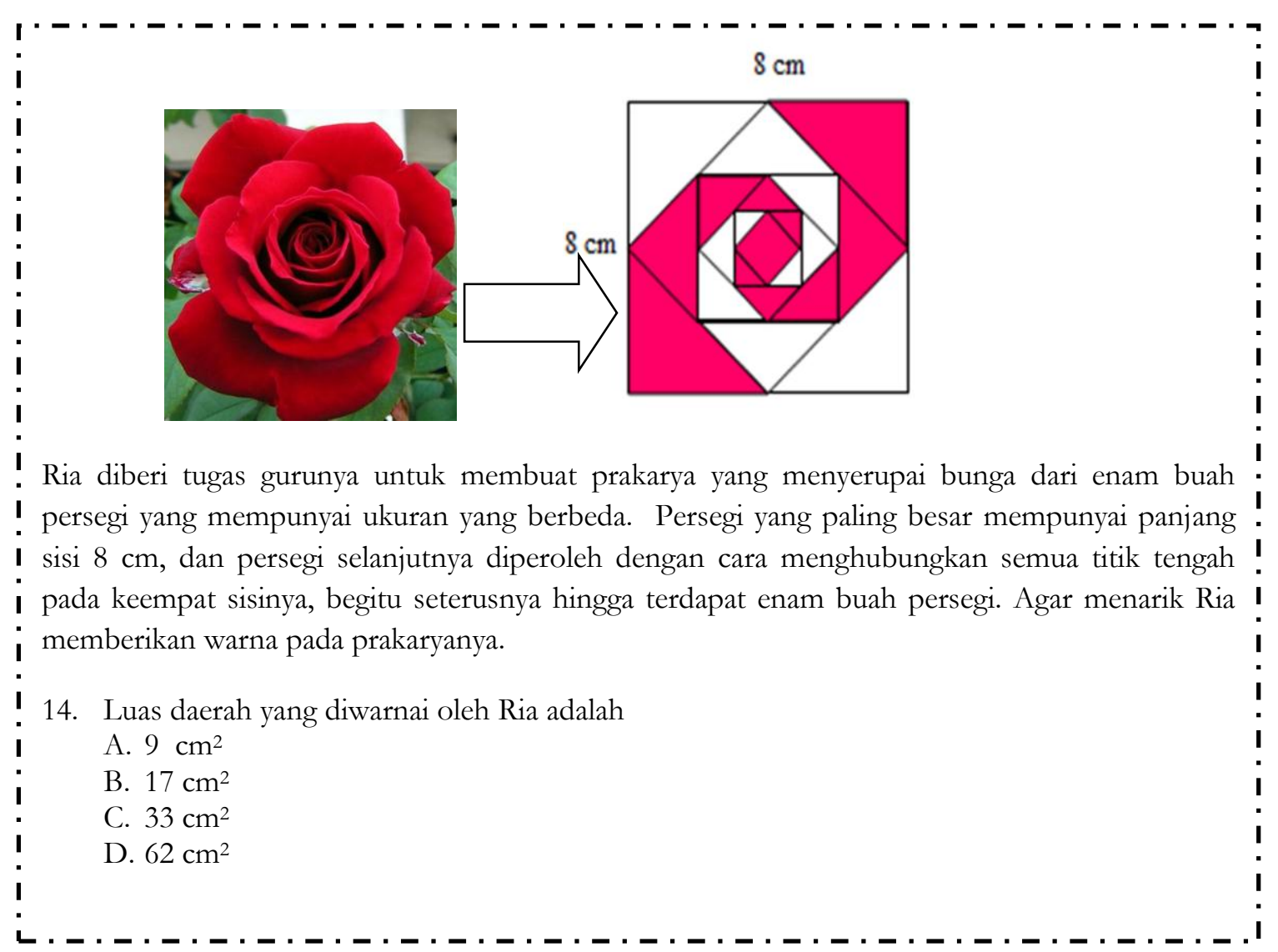

Gambar 2. Revisi dari Prototype I (Prototype II)

Small group

Tahap ini bertujuan untuk melihat kepraktisan soal-soal penalaran pada prototype II. Uji coba small group terdiri dari enam siswa kelas VIII.5 SMPN 1 Palembang. Siswa-siswa tersebut diminta untuk mengerjakan soal penalaran yang diberikan oleh peneliti. Setelah mengerjakan soal-soal pilihan ganda tersebut, siswa diminta untuk memberikan komentar tentang soal-soal yang telah dikerjakan dengan menjawab be- berapa pertanyaan pada lembar yang telah disediakan.

Hasil uji coba small group, diketahui bahwa dari 15 soal yang diberikan hanya ada 2 soal yang perlu direvisi kembali. Hal ini menunjukkan bahwa soal-soal yang dikembangkan telah praktis. Perubahan sebelum dan sesudah revisi berdasarkan hasil uji coba small group dapat dilihat dalam Tabel 1.

Tabel 1. Perubahan Sebelum dan Sesudah Revisi

\begin{tabular}{lll}
\hline \multicolumn{1}{c}{ Saran } & \multicolumn{1}{c}{ Sebelum Revisi } & \multicolumn{2}{c}{ Sesudah Revisi } \\
\hline $\begin{array}{l}\text { 1. Revisi kalimat soal nomor } \\
5 .\end{array}$ & $\begin{array}{l}\text { 1. Soal no. } 5 \text { menggunakan kali- } \\
\text { mat "luas sisi-sisi suatu dadu } \\
\text { adalah } 21 / 4 \mathrm{~cm}^{2} \text { " }\end{array}$ & $\begin{array}{l}\text { 1. Kalimat diganti menjadi } \\
\text { "luas setiap sisi suatu } \\
\text { dadu...." }\end{array}$ \\
$\begin{array}{l}\text { 2. Revisi pokok kalimat soal } \\
\text { nomor 9. }\end{array}$ & $\begin{array}{l}\text { 2. Soal no. } 9 \text { tidak dilengkapi } \\
\text { ke-terangan bahwa berat dari } \\
\text { satu bata merupakan bilang- } \\
\text { an asli }\end{array}$ & $\begin{array}{l}\text { 2. Pokok soal ditambah kali- } \\
\text { mat "jika berat dari satu } \\
\text { bata merupakan bilangan } \\
\text { asli". }\end{array}$ \\
\hline
\end{tabular}


Sebelum masuk pada tahap field test, soal prototype II diuji coba ke siswa kelas VIII.6 SMPN 1 Palembang yang berjumlah 30 siswa. Hasilnya dilakukan analisis untuk melihat tingkat kesukaran soal, daya pem- beda, dan juga reliabilitas dari 15 soal yang telah dikembangkan. Tingkat kesukaran butir soal pada ujicoba menunjukkan hasil seperti pada Tabel 2.

Tabel 2. Tingkat Kesukaran Butir Soal

\begin{tabular}{cccccc}
\hline Butir Soal & Jumlah benar & $\begin{array}{c}\text { IK } \\
\text { (proporsi) }\end{array}$ & Butir Soal & Jumlah benar & $\begin{array}{c}\text { IK } \\
\text { (proporsi) }\end{array}$ \\
\hline 1 & 20 & 0,74 & 9 & 18 & 0,67 \\
2 & 24 & 0,89 & 10 & 20 & 0,74 \\
3 & 10 & 0,37 & 11 & 17 & 0,63 \\
4 & 11 & 0,41 & 12 & 8 & 0,30 \\
5 & 18 & 0,67 & 13 & 19 & 0,70 \\
6 & 23 & 0,85 & 14 & 11 & 0,41 \\
7 & 20 & 0,74 & 15 & 8 & 0,30 \\
8 & 18 & 0,67 & & & \\
\hline
\end{tabular}

Keterangan: IK = Indeks Kesukaran

Sumber: Dokumen Peneliti

Tafsiran taraf kesukaran butir soal diklasifikasikan sebagai berikut: soal sukar mempunyai indeks $0,00-0,30$, soal sedang mempunyai indeks $0,31-0,70$, dan soal mudah mempunyai indeks 0,71-1,00 (Arikunto, 2012, p.225). Tahap uji coba menghasilkan soal yang dikategorikan mudah se- banyak 33,33\%, kategori sedang sebanyak $53,33 \%$, dan kategori sulit sebanyak $13,33 \%$.

Analisis daya beda butir soal pada uji coba menghasilkan soal dengan indeks daya beda butir soal yang disajikan pada Tabel 3.

Tabel 3. Indeks Pembeda Butir Soal

\begin{tabular}{ccccccccc}
\hline Butir soal & 1 & 2 & 3 & 4 & 5 & 6 & 7 & 8 \\
\hline Indeks pembeda & 0,27 & 0,40 & 0,13 & 0,47 & 0,53 & 0,07 & 0,13 & 0,40 \\
& & \multicolumn{7}{c}{ Lanjutan } \\
\hline Butir soal & 9 & 10 & 11 & 12 & 13 & 14 & 15 \\
\hline Indeks pembeda & 0,53 & 0,27 & 0,60 & 0,13 & 0,73 & 0,20 & 0,53 \\
\hline
\end{tabular}

\section{Sumber: Dokumen Peneliti}

Daya pembeda butir soal diklasifikasikan sebagai berikut: daya pembeda butir soal dengan klasifikasi soal tidak dipakai/ dibuang mempunyai daya beda $0,00-0,19$, soal diperbaiki mempunyai daya beda 0,20 - 0,29, soal diterima tetapi diperbaiki mempunyai daya beda $0,30-0,39$, soal diterima 
baik sekali (excellent) mempunyai daya beda 0,40 - 1,00 (Wahidmurni, 2010, p.136).

Tahap uji coba menghasilkan soal dengan klasifikasi sebagai berikut: soal yang tidak dipakai sebanyak $26,67 \%$, soal dengan klasifikasi diperbaiki sebanyak $20 \%$, dan soal yang diterima dengan baik sebanyak 53,33\%. Dari komentar siswa small group dan analisis butir soal pada tahap uji coba, maka soal-soal pada prototype II diperbaiki sehingga menghasilkan prototype III.

\section{Field Test}

Setelah diperoleh prototype III yang valid dan praktis, maka dilakukan uji coba field test untuk melihat efek potensial terhadap kemampuan penalaran matematis siswa. Pelaksanaan field test dilakukan pada tanggal 4 Juni 2013 di kelas VIII.7 SMPN 1 Palembang dengan jumlah siswa sebanyak 27 siswa. Sebanyak 15 soal diselesaikan oleh siswa dalam satu kali pertemuan selama 120 menit. Siswa menjawab soal dengan cara memilih jawaban yang benar pada bagian option dan diminta untuk menuliskan alasan/langkah pengerjaan mereka yang mendukung pemilihan jawaban tersebut. Salah satu soal yang ada pada prototype III dapat dilihat pada Gambar 3.

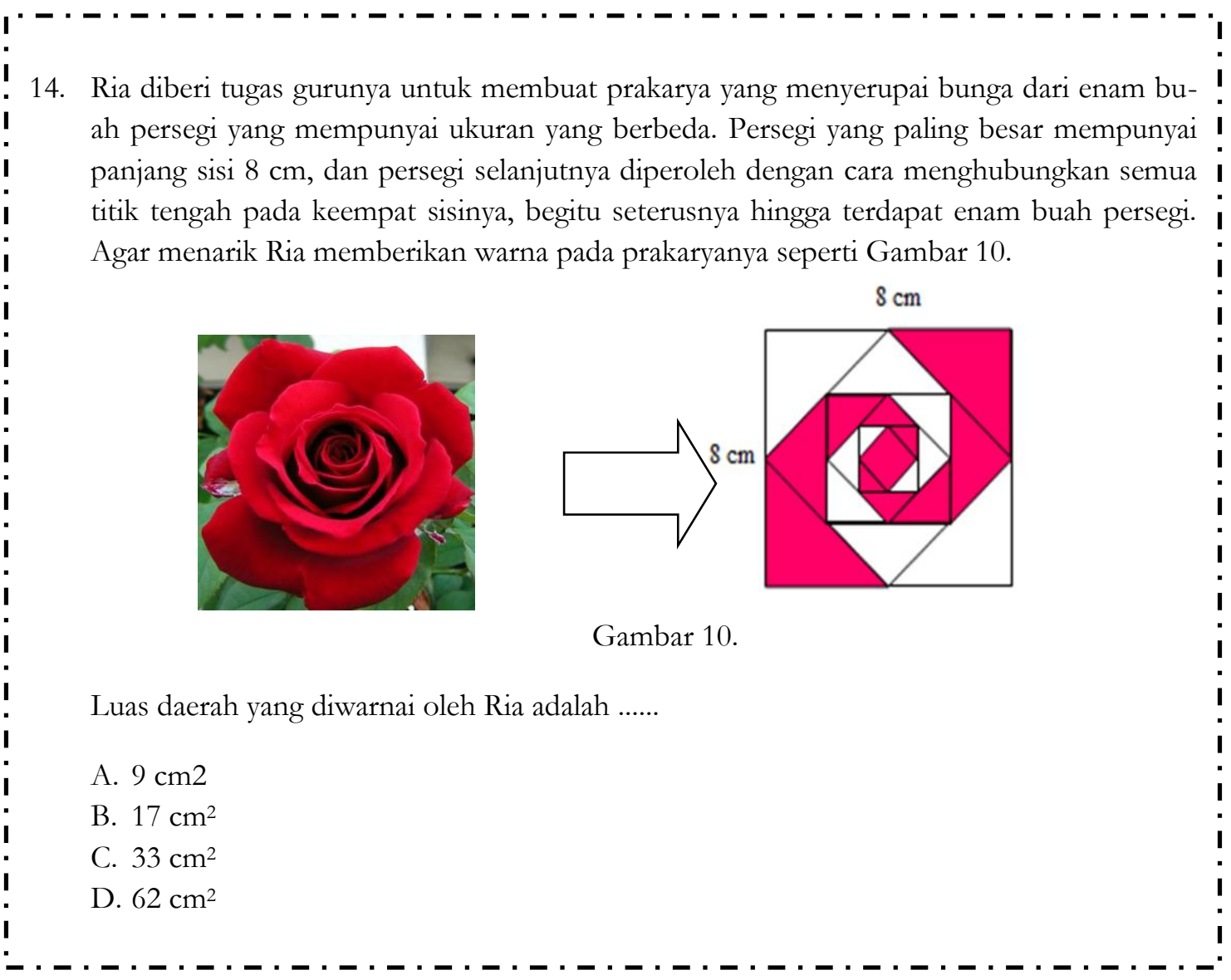

Gambar 3. Salah Satu Soal yang Ada pada Prototype III

Hasil penelitian terhadap soal penalaran model TIMSS dikategorikan menjadi 5 bagian yaitu sangat tinggi, tinggi, sedang, rendah, dan sangat rendah. Pengkategorian data tersebut dapat dilihat pada Tabel 4 
Tabel 4. Penentuan Kategori Kemampuan Penalaran Matematis

\begin{tabular}{cc}
\hline Nilai Siswa & $\begin{array}{c}\text { Tingkat Kemampuan } \\
\text { Penalaran Matematis Siswa }\end{array}$ \\
\hline $84-100$ & Sangat tinggi \\
$65-84$ & Tinggi \\
$45-64$ & Sedang \\
$25-44$ & Rendah \\
$0-24$ & Sangat Rendah \\
\hline
\end{tabular}

Distribusi frekuensi data kemampuan matematis siswa berdasarkan pengkategorian dapat dilihat pada Tabel 5 .

Tabel 5. Distribusi Frekuensi Tes Siswa Saat Field Test

\begin{tabular}{cccccccccccc}
\hline Interval & \multicolumn{2}{c}{ Generalize } & \multicolumn{2}{c}{ Analyze } & \multicolumn{2}{c}{ Integrate } & \multicolumn{2}{c}{ Justify } & \multicolumn{2}{c}{$\begin{array}{c}\text { Non-routine } \\
\text { problems }\end{array}$} \\
\cline { 2 - 11 } Nilai & frek & $\%$ & frek & $\%$ & frek & $\%$ & frek & $\%$ & frek & $\%$ \\
\hline $85-100$ & 3 & 11,11 & 8 & 29,63 & 1 & 3,7 & 1 & 3,7 & 5 & 18,52 \\
$65-84$ & 0 & 0 & 4 & 14,82 & 7 & 25,93 & 0 & 0 & 9 & 33,33 \\
$45-64$ & 16 & 59,26 & 0 & 0 & 8 & 29,63 & 16 & 59,26 & 0 & 0 \\
$25-44$ & 0 & 0 & 14 & 51,85 & 8 & 29,63 & 0 & 0 & 10 & 37,04 \\
$0-24$ & 8 & 29,63 & 1 & 3,70 & 3 & 11,11 & 10 & 37,04 & 3 & 11,11 \\
\hline
\end{tabular}

Sumber: Dokumen Peneliti

Tabel 6. Rata-Rata Distribusi Frekuensi Tes Siswa saat Field Test

\begin{tabular}{cccc}
\hline Interval & \multirow{2}{*}{ Kategori } & \multicolumn{2}{c}{ Rata-rata } \\
\cline { 3 - 4 } Nilai & & frekuensi & $\%$ \\
\hline $85-100$ & Sangat tinggi & 4 & 14,815 \\
$65-84$ & Tinggi & 4 & 14,815 \\
$45-64$ & Sedang & 8 & 29,63 \\
$25-44$ & Rendah & 6 & 22,22 \\
$0-24$ & $\begin{array}{l}\text { Sangat } \\
\text { rendah }\end{array}$ & 5 & 18,52 \\
\hline
\end{tabular}

Sumber: Dokumen Peneliti

Hasil tes soal penalaran siswa saat field test pada 27 siswa, diketahui: (1) berdasarkan kemampuan penalaran generalize yang termasuk dalam kategori sangat baik berjumlah 3 siswa (11,11\%), kategori sedang berjumlah 16 siswa (59,26\%), dan kategori sangat rendah berjumlah 8 siswa $(29,63 \%)$; (2) berdasarkan kemampuan penalaran analyze yang termasuk kategori sangat baik berjumlah 8 siswa $(29,63 \%)$, kategori tinggi berjumlah 4 siswa $(14,82 \%)$, kategori rendah sebanyak 14 siswa $(51,85 \%)$, dan kategori sangat rendah sebanyak 1 siswa $(3,70 \%)$; (3) berdasarkan kemampuan penalaran integrate yang termasuk kategori sangat tinggi sebanyak 1 siswa (3,7\%), kategori tinggi berjumlah 4 siswa $(14,82 \%)$, kategori sedang dan rendah masing-masing berjumlah 8 siswa $(29,63 \%)$, dan kategori sangat rendah berjumlah 3 siswa (11,11\%); (4) berdasarkan kemampuan penalaran justify yang termasuk 
dalam kategori sangat baik berjumlah 1 siswa $(3,7 \%)$, kategori sedang berjumlah 16 siswa $(59,26 \%)$, dan kategori sangat rendah berjumlah 10 siswa $(37,04 \%)$; (5) berdasarkan kemampuan penalaran solve non-routine problem yang termasuk dalam kategori sangat baik berjumlah 5 siswa $(18,52 \%)$, kategori tinggi berjumlah 9 siswa $(33,33 \%)$, kategori rendah berjumlah 10 siswa (37,04\%), dan kategori sangat rendah berjumlah 3 siswa $(11,11 \%)$.

Rata-rata distribusi frekuensi tes siswa saat field test pada 27 siswa, diketahui bahwa 4 siswa $(14,815 \%)$ tergolong mempunyai penalaran yang sangat baik, 4 siswa $(14,815 \%)$ tergolong mempunyai penalaran yang baik, 8 siswa $(29,63 \%)$ tergolong mempunyai penalaran yang sedang, 6 siswa $(22,22 \%)$ tergolong mempunyai penalaran yang rendah, dan 5 siswa $(18,52 \%)$ tergolong mempunyai penalaran yang sangat rendah.

\section{Pembahasan}

Penelitian ini menghasilkan soal penalaran model TIMSS matematika SMP yang telah dikembangkan berdasarkan langkahlangkah yang dikemukakan oleh Tessmer (1998, p.35). Berdasarkan hasil deskripsi dari tahap persiapan dan uji validitas isi dari ahli menunjukkan soal-soal yang dikembangkan sudah sesuai dengan indikator penalaran pada TIMSS. Berdasarkan hasil analisis jawaban siswa saat field test, dari 15 soal pilihan ganda model TIMSS, sebagian siswa mempunyai kemampuan penalaran matematis dengan baik. Hal tersebut dapat terlihat dari jawaban dan alasan yang diberikan pada lembar jawaban. Indikator-indikator penalaran seperti menganalisis permasalahan secara matematis, memberikan penjelasan dengan menggunakan model atau pernyataan matematika, mengintegrasi fakta dan prosedur matematika untuk mendapatkan solusi akhir, membuat generalisasi dari suatu permasalahan dan menyelesaikan permasalahan nonrutin telah terlihat.

Walaupun demikian, ada beberapa siswa yang mampu memahami soal namun masih kesulitan untuk memberikan penje- lasan dengan menggunakan model atau pernyataan matematika serta masih kesulitan untuk membuat pernyataan yang mendukung/menyangkal argumen. Selain itu, juga terdapat siswa yang tidak mampu mengerjakan soal karena tidak memahami soal dengan baik. Jika dilihat dari domain penalaran TIMSS, maka siswa masih kesulitan dalam menyelesaikan masalah nonrutin. Hal tersebut terlihat dari kesulitan siswa dalam memecahkan susunan masalah dengan cara matematika dan menerapkan fakta-fakta, konsep, dan prosedur-prosedur matematika dalam konteks yang kompleks dan tidak familiar. Siswa hanya mampu mengerjakan masalah nonrutin sampai pada tahap identifikasi masalah.

Secara keseluruhan berdasarkan hasil analisis jawaban siswa disimpulkan bahwa soal-soal yang telah dikembangkan dapat dipahami dengan baik oleh siswa. Hal tersebut ditunjukkan dengan sebagian siswa yang dapat menjawab soal dengan tepat dan munculnya indikator penalaran mate-matis dari uraian jawaban siswa. Selain itu, dari komentar siswa pada kelas field test diketahui bahwa secara umum soal-soal pilihan ganda model TIMSS yang diberikan dapat memancing siswa untuk berpikir lebih keras dan harus menggunakan nalar dan logikanya dalam menyelesaikan soal. Berdasarkan uraian yang telah dijelaskan sebelumnya maka dapat disimpulkan bahwa soal-soal penalaran model TIMSS yang telah dikembangkan memiliki efek potensial terhadap kemampuan penalaran matematis siswa SMP khususnya siswa kelas VIII SMPN 1 Palembang.

\section{Simpulan dan Saran}

Berdasarkan hasil penelitian, maka dapat disimpulkan bahwa soal penalaran model TIMSS matematika SMP yang dikembangkan sudah memenuhi kriteria valid dan praktis. Valid secara teoretik dapat dilihat dari hasil penilaian validator, yang semua validator menyatakan soal telah baik berdasarkan content, construct dan bahasa. Secara praktis tergambar dari hasil uji coba one-to-one, dan small group yang semua siswa 
dapat menggunakan perangkat soal dengan baik.

Berdasarkan hasil penelitian dan kesimpulan, maka disarankan kepada peneliti lain agar dapat mengembangkan soal penalaran untuk tingkat SD dan SMA sehingga dapat membantu guru untuk memperkaya variasi pemberian soal matematika dalam proses pembelajaran.

\section{Daftar Pustaka}

Arikunto, Suharsimi. (2009). Dasar-dasar evaluasi pendidikan. Jakarta: PT Bumi Bumi Aksara.

(2012). Dasar-dasar evaluasi pendidikean edisi 2. Jakarta: PT Bumi Bumi Aksara.

Brodie, Keraf. (2010). Teaching Mathematical Reasioning in Secondary School Classrooms. New York: Springer.

Emilya, D., Darmawijoyo,\& Ilma, R. (2010). "Pengembangan soal-soal open-ended materi lingkaran untuk meningkatkan penalaran matematika siswa kelas VIII sekolah menengah pertama negeri 10 palembang". Jurnal Pendidikan Matematika. Vol. 4, No. 2, hlm. 8-18.

Iryanti, Puji. (2010). "Potret pengajaran matematika SMP kelas 8 di Indonesia”. Jurnal Edukasi Matematika. Vol. 1, No. 2, hlm. 108-115.

Jurnaidi. (2012). Pengembangan soal model PISA pada konten change and relationship untuk mengetahui kemampuan penalaran matematis siswa SMP. Palembang. Tesis Universitas Sriwijaya: Tidak dipublikasikan.

Keraf, Gorys. (1982). Argumen dan narasi. Komposisi Lanjutan III. Jakarta: PT. Gramedia.

Mullis, I., et al. (2009). TIMSS 2011 Assesment framework. Chesnut Hills: Boston College.
Nieveen, Nienke. (2007). Formative evaluation in educational design research (Eds). An Introduction to Educational Design Research. Enschede: SLO.

Permana, Y \& Utari, S. (2007). Mengembangkan kemampuan penalaran dan koneksi matematik siswa sma melalui pembelajaran berbasis masalah. Jurnal Educationist, Vol. 1, No. 2, Juli 2007, blm. 116-123.

Tessmer, Martin. (1998). Planning and conducting formative evaluations: improving the quality of education and training. London: Kogan Page.

Van den Akker, J. (1999). Principles and methods of development research. In (Eds). Design Approaches and Tools in Education and Training, pp.1-14. Dordrecht: Kluwer Academic Publishers.

Van den Walle, J. (2008). Matematika sekolah dasar dan menengah pengembang-an pengajaran. Jakarta: Erlangga.

Wahidmurni, M. A., \& Ridho, A. (2010). Evaluasi pembelajaran kompetensi dan praktik. Malang: Nuha Litera.

Yunengsih, Y, Widiatmika, I.M.A, \& Candrasari, A. (2008). Ujian nasional dapatkah menjadi tolak ukur standar nasional pendidikan? (hasil kajian ujian nasional matematika pada sekolah menengah pertama). Jakarta: Departemen Riset Putera sampoerna Foundation.

Zulkardi, Z. (2002). Developing a learning environment on realistic mathematics education for Indonesian student teachers. Doctoral dissertation. Enschede: University of Twente, Enschede. The Netherland. (Online). Tersedia: http: //doc.utwente.nl/58718/1/ thesis_ Zulkardi.pdf. diakses tanggal 12 oktober 2011. 